\title{
Utopía y Praxis Latinoamericana
}

Dep. legal: ppi $201502 Z U 4650$

Esta publicación científica en formato digital es continuidad de la revista impresa ISSN $1315-5216$

Depósito legal pp $199602 Z U 720$

\section{Revista Internacional de Filosofía Iberoamericana}

\section{y Teoría Social}

Universidad del Zulia, Maracaibo, Venezuela

Facultad de Ciencias Económicas y Sociales

Centro de Estudios Sociológicos y Antropológicos (CESA)

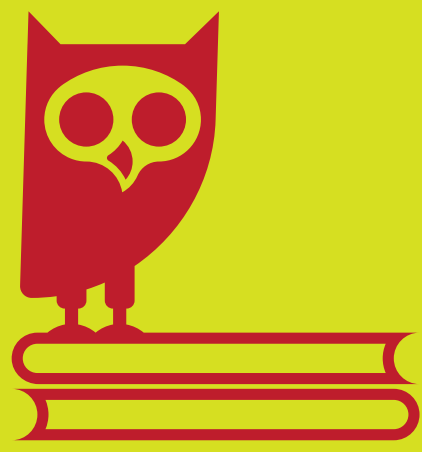

$\frac{\text { AÑ } 20, N^{\circ} 71}{\text { Octubre - Diciembre }}$

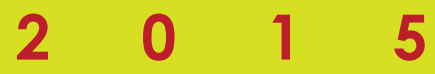




\title{
Articuos
}

UTOPÍA Y PRAXIS LATINOAMERICANA. AÑO: 20, No. 71 (OCTUBRE-DICIEMBRE), 2015, PP 41-66

REVISTA INTERNACIONAL DE FILOSOFÍA Y TEORÍA SOCIAL

CESA-FCES-UNIVERSIDAD DEL ZULIA. MARACAIBO-VENEZUELA.

\section{Ross on the Dualism of Reality and Validity} Ross y el dualismo de la realidad y la validez

\author{
Torben SPAAK ${ }^{1}$ \\ Professor of Jurisprudence, Department of Law, Stockholm University.
}

\begin{abstract}
Resumen
En este artículo, quiero considerar la intrigante crítica de la dualidad de la realidad y la validez elaborada en 1946 por Alf Ross y las implicaciones de esta crítica para las llamadas teorías de doble naturaleza de la ley, tales como la teoría defendida por Robert Alexy. El significado de este dualismo, que Ross considera estar en la base del pensamiento jurídico tradicional, es que tanto el propio concepto de derecho y algunos otros conceptos jurídicos fundamentales - tales como el concepto de las fuentes del derecho y el concepto de derecho subjetivo (que abarca el concepto de un derecho legal y el concepto de un deber legal) - constan de dos partes, una factual y empírica y una normativa y metafísica. Ross objeta, sin embargo, que este dualismo da lugar a ciertas antinomias muy problemáticas, tanto en el concepto de la ley como en los otros conceptos jurídicos fundamentales, y que los dualistas no pueden evitar estas antinomias eliminando el concepto de validez de sus teorías, ya que hacerlo dejaría la teoría resultante (monista) sin encontrar incluso su objeto de estudio, debiendo sustituir una explicación no-cognitivista de afirmaciones de validez legal por la explicación no-naturalista (intuicionista) característica de este dualismo.

Voy, sin embargo, a argumentar que la discusión de Ross sobre la dualidad de la realidad y la validez y las antinomias resultantes, aunque muy interesante, no son en última instancia, persuasivas; que la solución propuesta por Ross al problema de las antinomias probablemente habría tenido éxito si en realidad hubiera sido un problema que necesitase una solución; y que en cualquier caso la crítica de la dualidad de la realidad y la validez de Ross no se aplica a la teoría de la doble naturaleza de la ley de Robert Alexy.
\end{abstract}

Palabras clave: Ross; realidad; dualismo; teoría de la ley de naturaleza doble; Alexy.

\section{Abstract}

In this article, I want to consider Alf Ross's intriguing 1946 critique of the dualism of reality and validity and the implications of this critique for so-called dual-nature theories of law, such as the theory defended by Robert Alexy. The meaning of this dualism, which Ross considers to be at the foundation of traditional legal thinking, is that both the very concept of law and certain other fundamental legal concepts - such as the concept of the sources of law and the concept of subjective law (which encompasses the concept of a legal right and the concept of a legal duty) - consist of two parts, one factual and empirical and one normative and metaphysical. Ross objects, however, that this dualism gives rise to certain very troublesome antinomies both in the concept of law and in the other fundamental legal concepts, and that dualists cannot avoid these antinomies by eliminating the concept of validity from their theories, since doing so would leave the resulting (monist) theory unable to even find its study object, but must instead substitute a non-cognitivist account of claims of legal validity for the non-naturalist (intuitionist) account characteristic of such dualism.

I am, however, going to argue that Ross's discussion of the dualism of reality and validity and the ensuing antinomies, although very interesting, is ultimately not persuasive, that the solution proposed by Ross to the problem of the antinomies would likely have been successful if there really had been a problem that needed a solution, and that in any case Ross's critique of the dualism of reality and validity does not apply to Robert Alexy's dualnature theory of law.

Keywords: Ross; reality; dualism; dual-nature theory of law; Alexy.

1 I would like to thank Jes Bjarup, Åke Frändberg, Thomas Mautner, and Lennart Åqvist for helpful comments on the article and Robert Carroll for checking my English. The usual caveat applies, of course: The author alone is solely responsible for any remaining mistakes and imperfections. 


\section{INTRODUCTION}

In this article, I want to consider the legal philosophy of the Dane Alf Ross, who together with the Swede Karl Olivecrona ${ }^{2}$ was the most prominent of the Scandinavian realists. I want to consider, more specifically, Ross's intriguing 1946 critique of the dualism of reality and validity and the implications of this critique for so-called dual-nature theories of law, such as the dual-nature theory defended by RobertAlexy. The meaning of this dualism, which Ross considers to be at the foundation of traditional legal thinking, is that both the very concept of law and certain other fundamental legal concepts - such as the concept of the sources of law and the concept of subjective law (which encompasses the concept of a legal right and the concept of a legal duty) - consist of two parts, one factual and empirical and one normative and metaphysical. Ross objects, however, that this dualism gives rise to certain very troublesome antinomies both in the concept of law and in the other fundamental legal concepts, and that dualists cannot avoid these antinomies by eliminating the concept of validity from their theories, since doing so would leave the resulting (monist) theory unable to even find its study object, but must instead substitute a non-cognitivist account of claims of legal validity for the non-naturalist (intuitionist) account characteristic of such dualism.

I find Ross's critique intriguing and well worthy of our attention. I am, however, going to argue (i) that it is doubtful whether there is in the concept of law a dualism of reality and validity of the type that Ross has in mind, (ii) that while the first antinomy in the concept of law and the first antinomy in the concept of the sources of law do arise, they have nothing to do with such a dualism of reality and validity, (iii) that the second antinomy in the concept of law and the second and third antinomies in the concept of the sources of law do not arise at all, (iv) that while the first and the second antinomies in the concept of subjective law do arise, they have nothing to do with such a dualism, and (v) that the third antinomy in the concept of subjective law does arise but can be handled. I am also going to argue (vi) that Ross's proposed solution to the problem of the antinomies would likely be successful if there really were a problem that needed a solution, and (vii) that in any case Ross's critique of the dualism of reality and validity does not apply to Robert Alexy's dual-nature theory of law. Finally, I am going to argue (viii) that Kelsen in his 1960 critique of Ross's analysis - where he objects inter alia that Ross mistakenly takes claims of legal validity to express a belief that the valid entity has a confused property - overshoots the mark, because he confuses Ross's non-cognitivist account of claims of legal validity with an error-theoretical account of such claims.

I begin by giving an outline of the philosophical foundations of Ross's legal philosophy (Section 2) and proceed to consider Ross's discussion of the dualism of reality and validity and the resulting antinomies in the concept of law (Section 3), in the concept of the sources of law (Section 4), and in the concept of subjective law (Section 5), as well as the solutions proposed by Ross to the various antinomies (Section 6). Having done that, I introduce Alexy's dual-nature theory of law and consider the question of whether Ross's critique of dualism would apply to Alexy's theory (Section 7). The article concludes with a critical discussion of Ross's critique of dualism (Section 8).

\section{NATURALISM AND NON-COGNITIVISM IN ROSS'S LEGAL PHILOSOPHY}

Ross is a naturalist and a non-cognitivist, and we might say that this combination of naturalism and non-cognitivism constitutes the philosophical foundation of his legal philosophy. But what is naturalism, and what is non-cognitivism? Writers on naturalism make a fundamental distinction between (i) ontological (or metaphysical) and (ii) methodological (or epistemological) naturalism. Ontological naturalism is a thesis 
about the nature of what exists: there are only natural entities and properties ${ }^{3}$. I shall assume here that a natural entity or property is an entity or property of the type that is studied by the social or the natural sciences, though I recognize that it is difficult to find a fully satisfying characterization of natural entities or properties ${ }^{4}$. Methodological naturalism requires that philosophical theorizing be continuous with the sciences. Brian Leiter ${ }^{5}$ makes a distinction between methodological naturalism that requires "results continuity" with the sciences and methodological naturalism that requires "methods continuity" and explains that whereas the former type of naturalism requires that philosophical theories be supported by scientific results, the latter requires that philosophical theories emulate the methods of inquiry and styles of explanation employed in the sciences. As he points out ${ }^{6}$, it is the "methods continuity" version that has been at the center of philosophical interest through the years, and it is this version that I have in mind when I speak of methodological naturalism in this article.

Ross makes it clear in On Law and Justice (1959) that he espouses both ontological and methodological naturalism. He maintains, inter alia, that jurisprudential idealism rests on the assumption that there are two distinct worlds (or realms) with two corresponding modes of cognition, namely (i) the world of time and space, which comprises the usual physical and psychological entities that we apprehend with the help of our senses, and (ii) the "world of ideas or validity", which comprises "various sets of absolutely valid normative ideas" and is apprehended by our reason ${ }^{7}$; and he points out that jurisprudential realism is concerned with the world of time and space and aims to attain knowledge of the law using the methods of modern empiricist science. As he puts it ${ }^{8}$, "[t]here is only one world and one cognition. All science is ultimately concerned with the same body of facts, and all scientific statements about reality — that is, those which are not purely logical-mathematical—are subject to experimental test."

Ross was not only a naturalist, but also a non-cognitivist. Non-cognitivists maintain that there is no moral reality or moral knowledge, and that moral judgments do not assert anything about anything and that therefore they cannot be true or false. Instead, they typically maintain that a person who makes (what appears to be) a moral judgment is simply expressing his feelings, attitudes or preference ${ }^{9}$, or prescribing a course of action (Hare 1981). On this type of analysis, the function of moral judgments is to influence people. This means that on the non-cognitivist analysis, terms like 'right,' 'duty,' and 'ought' lack cognitive meaning and do not refer, though they may have so-called emotive meaning ${ }^{10}$.

Ross's non-cognitivism was explicitly stated in a couple of early articles. For example, in a 1936 article celebrating the $25^{\text {th }}$ anniversary of the Pure Theory of Law, Ross maintains that we cannot conceive of law as a system of norms in the sense contemplated by Kelsen and others, because norms do not express propositions, do not refer to states of affairs, but simply express the speaker's attitudes or feelings. A normative claim, Ross ${ }^{11}$ insists, "does not have any meaning that can be expressed in abstraction from the reality of

3 See: POST, JF (1999). "Naturalism”, In: AUDI, R (Ed.,) (1999). The Cambridge Dictionary of Philosophy. $2^{\text {nd }}$ ed., pp. 596-597. Cambridge, Cambridge University Press.

4 On this see: COPP, D (2007). Morality in a Natural World. Cap. I. Cambridge, Cambridge University Press; RIDGE, M (2008). "Moral Non-Naturalism", in: ZALTA, EN (Ed.,) (2008). The Stanford Encyclopedia of Philosophy (Fall 2008 Edition). URL = <http://plato.stanford. edu/archives/fall2008/entries/moral-non-naturalism/>.

5 LEITER, B (2007). Naturalizing Jurisprudence. Oxford, Oxford University Press, pp. 34-35.

6 Ibid., p. 34.

7 Ibid., p. 65.

8 Ibid., p. 67.

9 BLACKBURN, S (1998). Ruling Passions. Oxford, Oxford University Press; HäGERSTRöM, A (2013). On the Truth of Moral Ideas. Trans by Tomas Mautner, in: ELIAESON, S; MINDUS, P and STEPHEN, P \& TURNER, T (Eds.,) (2013). Axel Hägerström and Modern Social Thought (European Studies in Social Theory), pp. 409-428. Oxford, The Bardwell Press. (Originally published under the title "Om moraliska föreställningars sanning" in: FRIES, M (Ed.,) (1939). Axel Hägerström, Socialfilosofiska uppsatser, pp. 35-65. Stockholm, Bonniers); STEVENSON, Ch L (1944. Ethics and Language. New Haven, Yale University Press.

10 See: STEVENSON, Ch L (1937). "The Emotive Meaning of Ethical Terms". Mind, New Series, 46, pp. 14-31.

11 ROSS, A (1936). "Den rene Retslæres 25-Aars-Jubilaeum" ["The Twenty-Fifth Anniversary of the Pure Theory of Law"]. Tidsskrift for 
experience. It is not a 'thought' the truth or falseness of which can be tested as something that is absolutely independent of its psychological experience"12.

Ross does not have much to say about meta-ethical questions in On Law and Justice, but his distinction between assertions, which can be true or false, and directives, which lack truth-value ${ }^{13}$, together with his comments on the idea of justice, suggest that he still adhered to the emotivist version of non-cognitivism in the late 1950's. As he puts it ${ }^{14}$, "[t]o invoke justice is the same thing as banging on the table: an emotional expression which turns one's demand into an absolute postulate."

\section{DUALISM IN THE CONCEPT OF LAW}

Ross opens his 1946 treatise Towards a Realistic Jurisprudence ${ }^{15}$ with the following words:

The starting point of the exposition in the present book is the view that the fundamental source of error in a number of apparently unconquerable contradictions in the modern theory of law is a dualism in the implied pre-scientific concept of law which more or less consciously forms the basis of the theories developed. It is the dualism of reality and validity in law, which again works itself out in a series of antinomies in legal theory.

Dualist theories, he explains ${ }^{16}$, conceive of law "at the same time as an observable phenomenon in the world of facts, and as a binding norm in the world of morals or values, at the same time as physical and metaphysical, as empirical and a priori, as real and ideal, as something that exists and something that is valid, as a phenomenon and as a proposition." And he proceeds to maintain that the concept of law as we know it does contain such a dualism:

Characteristic of the concept of law is the belief in an incarnation of the valid, the metaphysical, the ideal in the realm of the actual, the physical, the real. The law is not, like morality, pure ideality. But neither is it, like the tyranny of crude power, a purely empirical social reality. The law is both, valid and factual, ideal and real, physical and metaphysical, but not as two things coordinated, but as manifestation of validity in reality, which is only thereby qualified as law. The content of law, therefore, consistently leads to a spiritualistic metaphysic, to the assumption that there exist elements within the physical world which in their inmost essence are an incarnation of spiritual principles or rational ideas expressing supertemporal values. The concept of law is in principle couched in the categories of the so-called practical knowledge, only, that these are considered to be deprived of their purely a priori character, and [are] so to speak amalgamated with the categories of the knowledge of reality ${ }^{17}$.

Having thus characterized the concept of law as being dualistic in this sense and having considered some different types of theory of law that illustrate this type of dualism, such as the theories of Savigny, Lask,

rettsvitenskap [Journal for Legal Science], p. 313.

12 Translated into English by Robert Carroll. The Danish original reads as follows: "Det normative Udsagn besidder altsaa netop ingen Mening, der lader sig fremstille i Abstraktion fra den psykologiske Oplevelsevirkelighed. Det er ingen "Tanke," hvis Sandhed eller Falskhed kan prøves som noget, der er absolut uafhængigt af dens psykologiske Oplevelse.

13 ROSS, A (1959). On Law and Justice. Berkeley \& Los Angeles, University of California Press, pp. 6-11.

14 Ibíd., p. 274

15 As Ross points out in the preface, this book is based on an earlier publication in Danish, namely, ROSS, A (1934). Virkelighed og gyldighed i retslaeren. En kritik af den teoretiske retsvidenskabs grundbegreber. [Reality and Validity in the Theory of Law. A Critique of the Fundamental Concepts of Theoretical Legal Science]. Copenhagen, Levin \& Munksgaard; ROSS, A (1989-1946). Towards a Realistic Jurisprudence. A Criticism of Dualism in Law. Translated by Annie I. Fausbøll. Aalen: Scientia Verlag. (Originally published 1946 by Munksgaard, Copenhagen).

16 ROSS, A (1989-1946). Op. cit., p. 11.

17 Ibíd., p. 20. 
Radbruch, Binder, and others ${ }^{18}$, Ross turns to consider the antinomies that, as he sees it, arise from a dualistic concept of law. He begins, however, by discussing then current (1946) versions of legal positivism in order to show that they, too, suffer from these antinomies ${ }^{19}$. He does this because he anticipates that critics might want to object to his line of argument, that legal positivists do not operate with a notion of validity strong enough to give rise to the antinomies.

Legal positivism, he explains, has it that law is a historical product located in the world of time and space, and that a norm is a legal norm if, and only if, it can be traced back to a source of law ${ }^{20}$. As he puts $\mathrm{it}^{21}$, "[p]ositive law (the law of the land) is the sum total of norms engendered by an historical process which, by virtue of certain external, observable distinguishing marks (e.g. by legislation), qualifies the norm as legal. Hence valid law is an historical fact given by experience and independent of how this fact is evaluated." This, of course, is in keeping with the social thesis of legal positivism, according to which one can determine what the law is using (exclusively or essentially) factual criteria ${ }^{22}$.

Ross then formulates the first antinomy as follows 23 :

Thesis: "The validity of the law as law is determined relatively to certain relevant, historical phenomena."

Antithesis: "The relevant historical phenomena are determined relatively to the validity of the law as law." 24 .

If we express this idea in terms of valid legal norms and sources of law, we get something like the following: Whereas the validity of legal norms presupposes that these norms can be traced back to a source of law, the existence of such a source of law presupposes in turn that it is recognized by a valid legal order, that is, an order consisting of legally valid norms. Ross adds ${ }^{25}$ that the theories of prominent legal positivists, such as John Austin, Karl Bergbohm, Hans Kelsen, and John Chipman Gray, are all guilty of this type of circular reasoning. For they all hold that we can trace all valid legal norms back either to a sovereign lawgiver or to the courts, even though they cannot determine whether $\mathrm{X}$ is a sovereign lawgiver, or a court, without presupposing precisely the existence of a valid legal order that confers on $\mathrm{X}$ the property of being a source of law.

Ross's idea, then, is that legal positivists maintain both (a) that a norm is a legal norm if, and only if, it can be traced back to a source of law, and (b) that something is a source of law if, and only if, it is recognized by a valid legal order. As Neil MacCormick ${ }^{26}$ has noted, the same type of circularity problem plagues H. L. A. Hart's theory of law, according to which the rule of recognition is a rule that is practiced by judges and fulfills the function of determining whether any given rule is a rule of the system. For, MacCormick points out, while we need the rule of recognition to determine whether a given rule is really a legal rule (that is, a rule of the system), we also need rules of adjudication to determine who is a judge - if we have no judges, we will have no rule of recognition.

18 Ibid., pp. 33-38.

19 Ibid., pp. 53-57.

20 Ibid., pp. 53-55.

21 Ibid., p. 54.

22 On the social thesis see: e. gr., RAZ, J (1979). The Authority of Law. Oxford, Clarendon Press, pp. 37-52; WALUCHOW, WJ (1994). Inclusive Legal Positivism. Oxford, Oxford University Press, pp. 80-141; SPAAK, T (2003). "Legal Positivism, Law's Normativity, and the Normative Force of Legal Justification". Ratio Juris, 16, pp. 472-473.

23 ROSS, A (1989-1946). Op. cit., p. 57.

24 I have omitted the emphasis in the original.

25 ROSS, A (1989-1946). Op. cit., p, 61.

26 MAcCORMICK, N (1981). H. L. A. Hart. Stanford, Stanford University Press, pp. 108-109. 
What does this have to do with jurisprudential dualism? Ross's idea, I take it, is that in order to break out of the circle, legal positivists will have to invoke the concept of legal validity and argue that only sources of law recognized by a valid legal order, that is, a legal order consisting of legally valid norms, qualify as sources of law. But by invoking the property of legal validity, they are also transforming their monist theory into a dualist theory, one that includes not only real, but also ideal, elements, and in their (subsequent) effort to anchor law in reality they will be transforming the dualist theory back into a monist theory, namely, one that includes only real elements. This movement back and forth between thesis and the antithesis, Ross explains, is a never-ending process ${ }^{27}$ : "[T]he antinomy expresses not so much a direct contradiction as an interminable return to the starting-point. It is like looking down the endless vista of parallel mirrors."

The second antinomy is as follows ${ }^{28}$ :

Thesis: "The legal rule is a direct practical statement as to the validity of the law, and its theoretical value as a truth is derived relatively to this (the legal rule as an imperative)."

Antithesis: "The legal rule is a direct theoretical statement as to facts, and its validity as law is derived relatively to this (the legal rule as a (hypothetical) judgment)."29

Ross's idea, as I understand it, is that if we conceive of legal rules as imperatives (the thesis), we will be able to predict human behavior only if we also assume that the citizens will comply with the law, and this will lead us to the view that legal rules are hypothetical judgments about human behavior (the antithesis); and if we conceive of legal rules as hypothetical judgments about human behavior (the antithesis), we will be able to explain why people comply with the law only if we also assume that legal rules are imperatives, and this will lead us back to the view that legal rules are imperatives (the thesis). And, as in the case of the first antinomy, Ross maintains that legal thinking will keep moving from one endpoint of the continuum to the other, and back again. For as soon as one tries to stop at one endpoint, one will have to begin moving back towards the other endpoint, in order to be able to predict human behavior or explain why people comply with the law, as the case may be.

\section{DUALISM IN THE CONCEPT OF THE SOURCES OF LAW}

The doctrine of the sources of law, Ross explains, is a doctrine about certain historical facts, such as legislation, precedent, and custom, that endow a given norm with the quality of law, that is, a doctrine about the criteria judges should use for determining whether something is law. As he puts it, ${ }^{30}$ "[t]he concept 'legal source' (. . . ) denotes a certain general form, which is the epistemological basis for the knowledge that the normative content given therein is law"31. The general idea, then, is that a given norm is a legal norm if, and only if, it can be traced back to a source of law.

The sources of law thus conceived give us the legal raw material but do not say anything about how this raw material is to be interpreted and applied by judges and other law-appliers. The latter question,

28 Ibid., p. 74

29 Here, too, I have omitted the emphasis in the original.

30 Ross's first monograph, ROSS, A (1929). Theorie der Rechtsquellen. Leipzig, Deuticke. (Dissertation), is wholly devoted to the doctrine of the sources of law. In his discussion of this topic, in: ROSS, A (1989-1946). Op. cit., p. 126. Ross draws extensively on the earlier monograph.

31 I find Ross's emphasis on the epistemological aspect of the sources of law a bit misleading, because I consider this to be nothing more than a secondary property of a source of law. The primary property, as I see it, is the metaphysical property of determining that a norm that can be traced back to a source of law qualifies as a legal norm because it can be so traced back - if a given norm can be traced back to a source of law, it is a legal norm, and if it cannot be so traced back, it is not. 
as Ross notes, is dealt with by the so-called legal (or juridical) method, ${ }^{32}$ which includes the usual interpretive arguments (such as the textual, systemic, intentionalist (or historical), and purposive (or teleological) principles of statutory interpretation), the modalities of decision, as I call them, (that is, plain application, contra legem decision, strict and liberal interpretation, analogical application and e contrario decision), and certain other norms, such as the so-called rule of lenity, the principle of legality, and perhaps also the principle that rules that provide exceptions to a main rule should be strictly (narrowly) construed ${ }^{33}$.

But the concept of the sources of law is problematic, according to Ross, because it incorporates the above-mentioned dualism of reality and validity. The problem, he explains ${ }^{34}$, is that a source of law must simultaneously perform two very different functions, namely, (i) that of ensuring that judges and other lawappliers will actually apply the law and (ii) that of endowing law with validity. And as a result of this underlying problem, Ross continues, judges and other law-appliers faced with the problem of determining whether a given norm is a legal norm tend to move from an emphasis on formal sources of law to a more or less tacit use of substantive considerations ${ }^{35}$ : "In one way or another farther-reaching methods beyond this [that is, beyond formal sources] are nearly always presupposed, which imply material legal sources, that is to say, a law which does not originate from an authoritative form or establishment, but directly from certain material principles, ideas or purposes."

Having thus explained the problem in general terms, Ross proceeds to identify three distinct antinomies in the concept of the sources of law. Here is the first antinomy ${ }^{36}$ :

Thesis: "The propositions of the doctrine of the sources of law do not themselves belong to positive law, but are valid independently of a given positive system of law."

Antithesis: "The propositions of the doctrine of the sources of law vary from one legal system to another, and must therefore form part of these."37

This antinomy, which appears to be a special case of the first antinomy in the concept of law, thus concerns the question of the relation between the concept of law and the concept of the sources of law. The problem, as I understand it, is that we think of the sources of law, SL, of a certain legal order, $L O$, as both conceptually dependent on and conceptually independent of $L O$ at the same time. On the one hand, says Ross ${ }^{38}$, if the function of a given source of law, $S L_{1}$, is to determine whether a norm, $n$, belongs to $L O, S L_{1}$ "can only be developed from the concept of law itself," that is, from $L O$, so that the details of $S L_{1}$ will depend on the details of $L O$ (the antithesis). On the other hand, if $S L_{1}$ is what determines whether $n$ is a legal norm in the sense of belonging to $L O, S L_{1}$ needs to be conceptually independent of $L O$ in order to avoid the problem of circularity alluded to above (the thesis) - if $S L_{1}$ were dependent on $L O$ (=not independent of $L O$ ), it would presuppose the existence of the very property it was meant to explain, that is, legal validity. Hence the antinomy.

We see that Ross's view is that the antithesis means that any given doctrine of the sources of law must be precisely adapted to the particular characteristics of the relevant legal order, in order to be able to fulfill its function, and that this means that it must be dependent on that legal order. For

33 On the legal method, see: SPAAK, T (2007). Guidance and Constraint. The Action-Guiding Capacity of Theories of Legal Reasoning. Uppsala, lustus. Chap. 3.

34 ROSS, A (1989-1946). Op. cit., p. 129.

35 Ibid., p. 130.

36 Ibid., p. 131.

37 Here, too, I have omitted the emphasis in the original.

38 ROSS, A (1989-1946). Op. cit., p. 132. 
example, he says s $^{39}$ that "the question as to what importance should be attached to the motives of the law [the preparatory works] in the interpretation of it [the law] cannot be answered in the abstract from a consideration of the concept of law, but only with a view to a certain given state of law." As I understand it, he is saying that no doctrine of the sources of law that is independent of the relevant legal order (or "concept of law," as he says), could possibly account for, say, the fact that Swedish judges should, or that French judges should not, consider preparatory works when interpreting statutes.

Here is the second antinomy ${ }^{40}$ :

Thesis: "The supreme source of law (basis for the knowledge of law) is itself a norm or validity, not a fact."

Antithesis: "The supreme source of law is itself a fact, not a norm (validity)."

As Ross ${ }^{41}$ points out, this antinomy concerns the details of the definition of the concept of the sources of law. He reasons as follows. Following Kelsen, he notes that the law-creating power of the act of legislation presupposes a constitutional norm, according to which the legislative body has the legal competence to enact laws; and, he adds, the same goes for every other historical act, such as custom. Thus in every legal order there occurs also formation of customary law that is independent of statutory law, including the constitution. And if this procedure is to be legitimate, we need to posit a fundamental norm that makes it legitimate. But the problem with this move, he points out ${ }^{42}$ is that ". . . the fundamental norm itself cannot be posited independently of the actual course of events, the actual machinery of compulsion as such." For, he explains, "[i]f the system is not to be an arbitrary device, the fundamental norm must be chosen in such a way that it will 'accord with' the actual functioning system." Hence the antinomy.

Note that this (the second) antinomy in the concept of the sources of law is more or less identical to the first antinomy in the same concept and, therefore, more or less identical to the first antinomy in the concept of law. I do not, however, find it conducive to clarity to introduce the same antinomy twice, even thrice, using slightly different formulations.

Finally, we have the third antinomy ${ }^{43}$ :

Thesis: "The assumption of a multiplicity of original sources of law is an impossibility."

Antithesis: "The attempt to reduce the multiplicity of sources to a systematic unity is not practicable."

Ross ${ }^{44}$ explains that there are two reasons why it is impossible to assume a multiplicity of sources of law, namely, that doing so is incompatible (i) with the idea of the unity of the concept of law and (ii) with the idea of the unity of the content of the law derived from the sources of law. He points out, as regards (i), that if we assume a multiplicity of sources of law, we must be able to explain how that which is derived from one source is law in the same sense as that which is derived from another source, and that we can do this only by giving priority to one source, say, legislation, and reduce the other sources, such as precedent and custom, to that source. But, he objects, any attempt to reduce some sources to the others will inevitably lack any real foundation: 
If, for instance, we take legislation as a legal source because it expresses the will of the social power, it is incompatible with this to accept custom as a source at the same time, because it expresses the view of law of those who are subject to its norms. If it is the essence of law to be an expression of the will of the social power, all sources of law, not only statutory law, must be referable to this starting-point, the will of the social power. Authors who are consistent introduce various constructions of permission and authorization as a means to this end. It is not difficult to see, however, that such permissions to use certain subsidiary sources are quite fictive, and that, apart from the actual state of affairs, and perhaps the private estimate of the author in question, every real foundation for determining the content of the permission is lacking ${ }^{45}$.

He continues to argue ${ }^{46}$, as regards (ii), that in order to avoid a situation in which different sources of law give different answers to a legal question, it is necessary to arrange the different sources in a hierarchical order, so that a given source, ( $\beta$ ), will be considered only if a higher source, ( $\alpha$ ), is inapplicable. The problem with this arrangement, however, is that the judge will in most cases be unable to determine whether (a) is applicable or not, unless he evaluates the situation, and this in turn means that there will be no objective way to determine what is the content of law.

Ross does not, however, explain just why any attempt to reduce a multiplicity of sources to a systematic unity would not be practicable (the antithesis).

\section{DUALISM IN THE CONCEPT OF SUBJECTIVE LAW}

Following jurisprudential tradition, Ross ${ }^{47}$ makes a distinction between objective law in the sense of a set or a system of norms, that is, a legal system, and subjective law in the sense of such a set or a system that is in some sense at the disposal of a certain individual, who will then have a legal right or a legal duty (or a legal obligation). The conceptual relation between objective and subjective law, he continues ${ }^{48}$, depends on the nature of law. For example, assuming a natural law view of law, it is natural to think of legal rights as being conceptually prior to legal duties, and assuming a legal positivist view of law, it is natural to think of legal duties as being conceptually prior to legal rights. And if we choose to think of legal rights as being conceptually prior to legal duties, Ross ${ }^{49}$ explains, we will see that it is quite natural to analyze the concept of a legal right either in terms of interests (as Rudolf von Ihering did) or in terms of will (as Bernard Windscheid did).

But either way, he points out ${ }^{50}$, the idea of a specifically practical validity enters into the concept of subjective law, since we define the concept of law (conceived as a legal order) with the help of the concepts of a legal right or a legal duty, and since the latter concepts "belong to practical dogmatism, not to the knowledge of reality"s1.

51 I fail to understand Ross's train of thought here. If he wants to show that the idea of a specifically practical validity enters into the concept of subjective law, why invoke the fact, if it is a fact, that we define the concept of law in terms of the concepts of a legal right and a legal duty? Why not instead rest content with the claim that the concepts of a legal right and a legal duty "belong to practical dogmatism, not to the knowledge of reality"? 
Ross then introduces the first antinomy: ${ }^{52}$

Thesis: "The existence of subjective law is determined relatively to the actual function of the compulsory system."

The antithesis: "The actual function of the compulsory system is determined relatively to the existence of subjective law."

This antinomy, which concerns the relation between an efficacious legal order, on the one hand, and legal rights and legal duties, on the other, thus says that whereas the existence of subjective law presupposes the existence of an efficacious legal order ("a functioning compulsory system"), the existence of an efficacious legal order presupposes the existence of subjective law. So it reminds us of the old question of how to view the relation between social efficacy and legal validity: Should we say that a legal norm is valid because it is applied or that it is applied because it is valid ? $^{53}$ The former is the view held by legal realists, and the latter is Kelsen's (and many other legal scholars') view. As Kelsen ${ }^{54}$ sees $^{2}$ it, validity amounts to bindingness, where bindingness is different from, but not independent of, social efficacy. As should be clear, and as Ross points out ${ }^{55}$, this antinomy is a special case of the first antinomy in the concept of law.

Here is the second antinomy:

Thesis: "The duty-creating character of the consequences of compulsion is conditioned by their character as 'sanctions."'

Antithesis: "The character as 'sanctions' attaching to compulsion is conditioned by its following upon the contravention of a duty."

This antinomy thus says that the consequences of compulsion create a legal duty if, and only if, they qualify as a sanction, although they qualify as a sanction if, and only if, they follow from a breach of a legal duty; and, as Ross points out ${ }^{56}$, this antinomy is really a version ("a special formulation") of the first antinomy in the concept of subjective law. For this antinomy, too, makes it clear that the existence of a legal duty presupposes the existence of an efficacious legal order, whereas the existence of an efficacious legal order presupposes the existence of a legal duty.

Here is the third antinomy:

"The element of will in the concept of subjective law can neither be retained nor abandoned".

The reason why this is so, Ross ${ }^{57}$ explains, is that, on the one hand, the concept of will cannot be retained as a constituent part of the concept of subjective law, since we recognize children and mentally handicapped persons as right-holders even though they do not have the requisite will, and, on the other hand, that the concept of will cannot be eliminated as a constituent part of the concept of subjective law, since it is needed in order to distinguish between legal rights and mere reflexes (of another person's

52 As before, I have omitted the emphasis in the original. Cfr. ROSS, A (1989-1946). Op. cit., p. 171.

53 This in turn appears to be a version of the so-called Euthyphro problem (see: MATTHEWS, GB (1995). "The Euthyphro Problem", in: HONDERICKT (Ed.,). The Oxford Companion to Philosophy, p. 253. Oxford, Oxford University Press. When Euthyphro suggests in Plato's eponymous dialogue that to be pious is to be loved by the gods, Socrates counters with the question: Is the pious loved by the gods because it is pious, or is it pious because they love it?

54 KELSEN, H (1960). Reine Rechtslehre [The Pure Theory of Law]. $2^{\text {nd }}$ ed. (Reprint) Vienna, Österreichische Staatsdruckerei. (Originally published by Franz Deuticke, Vienna), pp. 215-221.

55 ROSS, A (1989-1946). Op. cit., p. 171.

56 Ibid., p. 172.

57 Ibid., p. 174. 
legal duty $)^{58}$. We might perhaps put it thus: The will theory of legal rights is both false (because of the existence of very young or mentally handicapped right-holders) and true (because of the need to distinguish between legal rights and reflexes) at the same time.

We see, then, that Ross's position is that we need the element of will to distinguish between a legal right and its reflex. But what does Ross mean by 'reflex' in this context? The problem he has in mind is that under the interest (or beneficiary) theory of legal rights - which has it that a person has a legal claim-right if, and only if, he is the intended beneficiary of another person's legal duty, that is, if (and only if) he is the person who has an (immediate) interest in the performance of the duty - a legal right turns out to be nothing more than a reflex of the (more fundamental) legal duty and therefore does not contribute anything of interest to legal thinking ${ }^{59}$. The insight of will-theorists is that a person has a legal right if, and only if, his will is recognized as controlling (in a certain sense) the other person's legal duty. This, then, is the reason why Ross says that we need the element of will in order to distinguish a legal right from a mere reflex.

Let us now proceed to consider Ross's purported solution to the problem of the antinomies.

\section{DISSOLVING THE ANTINOMIES: A NON-COGNITIVIST ACCOUNT OF CLAIMS OF LEGAL VALIDITY}

Since, as we have seen, the reason for the antinomies in the concept of law and in the concepts of the sources of law and of subjective law is one and the same, namely, the dualism of reality and validity identified by Ross and considered above, one may suspect that any solution to these antinomies should at bottom be the same. And, according to Ross, so it is. Accordingly, he attempts to dissolve the antinomies in all three concepts in the same way, namely, by substituting a non-cognitivist account of claims of legal validity for the non-naturalist account of such claims, which, as he sees it, gave rise to the underlying dualism in the first place. The point of doing so is, of course, to retain the concept of validity in legal thinking, while getting rid of the troublesome assumption that valid (or binding) legal norms exist in some sort of higher realm. To retain the concept of validity in legal thinking is very important, Ross explains, because any theory of law that eliminated this concept would fail spectacularly as a theory of law in that it would fail to even identify its study object, that is, law. As Ross sees it, if one does not have access to the concept of validity, one cannot determine whether a given norm is a legal norm or not, or whether a certain human behavior is legally relevant or not:

If the law is defined as a certain actual behaviour, dualism is, indeed, avoided to begin with. Statements about the law will be purely theoretical statements about what happens or what will happen. But this results in a complete disruption of the concept of law. For the question will arise how social conduct which is law can be precisely delimited from all other social conduct. Such a delimitation can not take place without going back to the notions of validity that it was attempted to avoid ${ }^{60}$.

Ross's idea is that the concept of validity, although admittedly absurd, symbolizes certain facts that are important to the study of law, but whose nature is not yet clear to us, namely, expressions

58 Ibid., pp.167-168.

59 Ibídem.

60 KELSEN, H (1999-1945). General Theory of Law and State. Trans. Anders Wedberg. Union, New Jersey, The Lawbook Exchange. (Originally published 1945 by the Harvard University Press, Cambridge, Mass), pp. 175-176, made essentially the same point when he objected to the claim by sociological jurisprudents that sociological jurisprudence is the only real science of law, that sociological jurisprudents cannot even determine what human behavior to focus their sociological study on, unless they invoke the concept of law employed by normative jurisprudents, a concept that is defined in terms of the concept of validity. ROSS, A (1989-1946). Op. cit., p. 49. 
Torben SPAAK

of certain peculiar psycho-physical experiences ${ }^{61}$ : "Our object in determining the concept of law is not to spirit away the normative ideas, but to put a different interpretation on them, reading them for what they are, the expression of certain peculiar psycho-physical experiences, which are a fundamental element in the legal phenomenon." Ross maintains, in keeping with this, that one cannot avoid the antinomies simply by giving up on the concept of legal validity and constructing a monist theory that focuses on either the real or the ideal dimension ${ }^{62}$ : "The sting of the problem lies in the very fact that the two points of view cannot be distinguished and isolated; the thesis is bound to lead to the antithesis, and vice versa. The interpretation by means of reality cannot be carried through without recourse to the category of validity, and the reverse."

He proceeds to argue that the dimension of validity, as it is understood in traditional theories of law, is a category of thought that is assumed to be distinct from, although in some sense parallel to, the category of reality. But, he explains ${ }^{63}$, the truth of the matter is that "there exist no notions of validity at all, but merely conceptually rationalized expressions of certain subjective experiences of impulses", that from a standpoint transcending consciousness, the notions of validity are simply "certain peculiar disinterested behaviour attitudes", and that owing to a natural illusion the human mind rationalizes these attitudes in "the idea of a 'validity' as something objectively given." And he therefore proposes ${ }^{64}$ that we substitute for the idea of validity in the sense explained "the experiences of validity (in the sense of certain actual behaviour attitudes) underlying this rationalisation and symbolised by it."

We see that Ross's non-cognitivism is at work here. On the non-cognitivist analysis, (firstorder) value judgments and claims of rights and duties and of validity do not (correctly or incorrectly) report moral facts, but express the feelings and attitudes of the speaker (or else prescribe a course of action). Once we see this, Ross reasons, we will not be deceived into imagining that there really are (objective) norms and values, which then have to be located in some sort of supersensible realm, such as Kelsen's 'world of the ought.' As fellow Scandinavian realist Karl Olivecrona ${ }^{65}$ puts it in an illuminating article on realism and idealism in legal philosophy, "[w]e are misled by our own feelings of being bound by the law into believing in these metaphysical relations."

The proposed solution to the problem of the antinomies is in keeping with Ross's fundamental assumption, that the science of law is part of the science of human behavior and that legal phenomena "must be found within the field of psycho-physical phenomena", ${ }^{66}$ and that the proper method here is to investigate and see what the realities are that have given rise to the rationalizations found in dualist theories. Ross maintains in keeping with this that the three elements that are characteristic of all dualist theories of law - namely, (i) the element of reality, (ii) the element of validity, and (iii) the element of logical interdependence of (i) and (ii) - correspond to and symbolize the following three factors all of which belong in the psycho-physical reality of law: "1) an interested behaviour attitude, more precisely determined as an impulse of fear of compulsion; 2) a disinterested behaviour attitude having the stamp of validity; and 3) an actual, inductive interaction between these factors in such a way that the existence of the former tends to cause and stabilize the existence of the latter, and vice versa" 67 .

61 Ibidem.

62 Ibid., p. 76.

63 Ibid., p. 77.

64 Ibidem.

65 OLIVECRONA, K (1951). "Realism and Idealism: Some Reflections on the Cardinal Point in Legal Philosophy", New York University Law Review, 26, p.131.

66 ROSS, A (1989-1946). Op. cit., p. 78.

67 Ibidem. Emphasis in the original. 
Ross then turns to a consideration of the antinomies in the concept of the sources of law ${ }^{68}$. He begins by noting that if we reject the traditional understanding of the concept of law and substitute for it a revised concept in which "the rationalisations of validity are reduced to what they are, namely symbolical expressions of irrational factors", and in which the idea of law as a system of norms has been rejected in favor of the idea of law "based on the study of psycho-physical facts of the juridical phenomena", we will see that both the concept and the problem of the sources of law will undergo a change of character. And, he continues ${ }^{69}$, if we keep in mind that legal knowledge, like all other knowledge, can only be gained through experience, and that "legal behavior attitudes are not immediately given statically, but develop dynamically from certain 'immediate ideas of competence' to authoritatively established normative expressions deduced from them"70, we see that the form that according to the doctrine of the sources of law is the source of legal validity is identical to the form of the authoritative establishment of legal norms, and that the power of this form to create legal validity is in turn a result of the competence to establish legal norms, which is nothing more than 'the rationalized expression of certain attitudes.'

What this means, then, is that we can account for the validity of legal norms by invoking certain attitudes, which are part of reality. And this in turn means, Ross points out, that the dualism of reality and validity in the concept of the sources of law will disappear. For, on this analysis, both the formal and the material (substantive) aspects of the sources of law will come to reflect two types of motivating factors in legal thinking, namely, "the authoritative formal decisions, in themselves bearing the stamp of legal validity prior to and independently of their application in a judicial decision, and the free material practical considerations, ideologies, and other motivating factors, which do not in themselves possess, but only through their application acquire, the stamp of legal validity"71.

Ross adds ${ }^{72}$ that the rejection of the dualism in the concept of the sources of law and the consequent dissolution of the antinomies will also influence our understanding of the legal (juridical) method. More specifically, the rejection of dualism makes it clear that interpreting a statute is not the logical matter of establishing in the abstract the complete and precise meaning of the provision in question, but rather the practical matter of determining the meaning of words according to ordinary usage $^{73}$. As he puts it, ${ }^{74}$ "[t]he decision does not depend on reflection and theoretical proofs, but on a psychological process of motivation, which will again largely depend on the practical interests associated with one or the other use of the word." For example, we now see that there really is no such thing as textual (or literal) interpretation, and that legal interpretation must be purposive (or teleological) (5. $^{\text {. This is }}$ so, he explains, because the question of whether a certain word or expression, such as 'house,' 'forest,' or 'farming,' covers a certain phenomenon is ultimately a practical, not a theoretical, question, which cannot be answered except by reference to what he calls the "practical interests" that are associated with various interpretations of the relevant legal norm:

The practical interests which are decisive here may be either those that directly dominate the judge as an individual influenced by his community, class, or profession, or they may be those which the judge supposes have influenced the legislator. From the history of how the law came into being he will

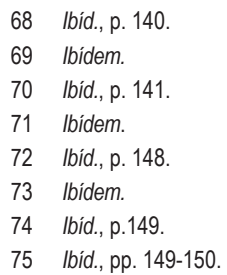


then try to ascertain the motives that has [sic] influenced the law-giver. Since however 'the lawgiver' as an expression of one will is a mere fiction, and since the law will as a rule have come into being as the resultant of various interest components, the difference between the two methods will not usually be very great $^{76}$.

Finally, he turns to consider the antinomies in the concept of subjective law ${ }^{77}$. Focusing on the concept of a legal right instead of the concept of a legal duty, he attempts to dissolve the three antinomies by rejecting the underlying idea that a legal right is a single entity that has magical properties, such as a power of dominion, and substituting for it the idea of a legal right as what he calls a technical right-concept. He puts the main idea as follows:

In rationalization rights are conceived as a quality of unity, a legal power of dominion, localized to a human individual, the subject of the rights. Three assumptions may be distinguished in this conception: the assumption that a right constitutes a unity; that the necessary basis of a right is a human subject; and that the nature of the right is the special legal control of an object. If a right is regarded as a technical figure in positive law, all three assumptions are false and apt to involve fictions, pseudo problems, and corruptions ${ }^{78}$.

Having discussed in some detail the advantages of substituting the concept of a legal right conceived as a technical right-concept for the concept of a legal right conceived as a concept of something that has unity and magical powers, Ross concludes that we can now easily dissolve the three antinomies that we have found in the concept of subjective law. He treats the first two antinomies together and points out that they will be dissolved as soon as we substitute the idea of an attitude to a behavior for what he calls the "rationalized fictions"

In these cases there is merely a special formation of the general antinomy between reality and validity in law, which, when the irrational realities are substituted for the rationalised fictions, resolve themselves in an interaction between actual compulsion and a disinterested behaviour-attitude (experience of validity $)^{79}$.

The third antinomy is different, however, he explains ${ }^{80}$, since it arises because of the peculiar dogmatism of the concept of subjective law. He notes that it expresses the antagonism between will theories and interest theories of legal rights, and that this antagonism does seem unconquerable. But, he explains $^{81}$, we know now that the problem is that the concept of a legal right is ambiguous and involves a false assumption of conceptual unity. If we manage to give up on the hopeless idea of conceptual unity and get rid of the ambiguities, the antagonism between will theories and interest theories of rights will disappear - that is, the antinomy will disappear.

Let us now turn to consider a contemporary example of dual-nature theories of law, namely, Robert Alexy's well-known and much-discussed theory of law.

\section{ALEXY'S DUAL-NATURE THEORY}

Robert Alexy maintains that law has a dual nature, in the sense that it necessarily consists of both a real and an ideal part, and that this feature ${ }^{82}$ is "the single most essential feature of law". He maintains,

76 Ibid., p. 150.

77 Ibid., Chap. 8-10.

78 Ibíd., p. 191.

79 Ibid., p. 202.

80 Ibídem.

81 Ibidem.

82 ALEXY, R (2010). "The Dual Nature of Law". Ratio Juris, 23, p. 180. 
more specifically, that the elements of authoritative issuance and social efficacy constitute the real part of law, whereas the claim to (moral) correctness makes up the ideal part. And, he points out, the dualnature thesis implies non-positivism ${ }^{83}$ : "[i]f one claims that social facts alone can determine what is and what is not required by law, that amounts to the endorsement of a positivistic concept of law. Once moral correctness is added as a necessary third element, the picture changes fundamentally. A non-positivistic concept of law emerges."

Alexy does not, however, say anything in this context about the nature of moral correctness. It is, however, clear from his earlier writings ${ }^{84}$ that he rejects not only all versions of non-cognitivism and relativism, but also both naturalist and non-naturalist versions of moral realism. Instead, he defends the view that practical, including moral, reasoning, is a rule-governed activity, and that one may properly speak of the correctness of practical - including moral - claims ${ }^{85}$. And in a later article ${ }^{86}$, he defends, in keeping with this, a Kantian conception of practical rationality (or practical reason) in the shape of a discourse theory, according to which "a norm is said to be correct precisely when it is or might be the outcome of a specific procedure." Since I have seen nothing in his more recent writings that suggests that he has abandoned this stance, I shall assume that Alexy is a meta-ethical constructivist. Note, however, that he does not maintain that discourse according to his rules of discourse will always yield "one right answer." For there might be cases in which the participants in the discourse reach conflicting conclusions, although they have both (or all) followed the rules of discourse. In such cases, Alexy ${ }^{87}$ is content to speak of a discursive possibility.

Alexy ${ }^{88}$ aims to establish the ideal component of law by means of the intriguing argument from performative contradiction, which features a hypothetical constitutional provision, according to which $X$ is a sovereign, federal, and unjust republic, and a court judgment, according to which the defendant is wrongly sentenced to life imprisonment because the law was interpreted incorrectly. The constitutional article reads as follows:

(CA) $X$ is a sovereign, federal, and unjust republic.

And the court judgment reads as follows:

(CJ) The defendant is - wrongly, because the valid law was interpreted incorrectly - sentenced to life imprisonment.

Alexy's strategy is to identify an absurdity in the very idea of a legal act - such as an act of legislation or a court judgment - that does not involve a claim to correctness, and to argue that this absurdity can only be explained by reference to the occurrence of a performative contradiction, which he considers to be a conceptual defect (in a broad sense). Beginning with (CA), he points out that the absurdity is clearly not due to a technical, moral, or conventional fault, but to a performative contradiction. What he means is that the reason why $(C A)$ is absurd is that the act of legislation necessarily involves the raising of a claim to correctness, and that this claim to correctness is contradicted by the content of (CA). To enact (CA), then, is to make a conceptual mistake (in a broad sense) Turning to (CJ), he applies the same type of reasoning and argues that the reason why $(\mathrm{CJ})$ is absurd is that the act of rendering a judgment necessarily involves the raising of a claim to correctness, and that this claim to correctness is

87 ALEXY, R (1989). Op. cit., pp. 206-208.

88 ALEXY, R (2010). Op. cit., p.169. 
contradicted by the content of $(\mathrm{CJ})^{89}$. Since this is so, we have in this case, too, a conceptual mistake (in a broad sense).

Having established to his satisfaction the existence of the ideal dimension of law, Alexy proceeds to point out that the insufficiency of the ideal dimension necessitates the existence of the real dimension of law. The necessity, he explains ${ }^{90}$, "stems from the moral requirements of avoiding the costs of anarchy and civil war and achieving the advantages of social co-ordination and co-operation." The idea, then, is simply that law needs a real part to ensure that people actually obey the law.

I have doubts about the cogency of Alexy's line of argument ${ }^{91}$, however, though I shall not pursue my objections to Alexy's line of argument here. Instead, I shall grant Alexy the conclusion that law necessarily has a dual nature. Does this mean, then, that Alexy's theory gives rise to antinomies of the type Ross identified in his critique of dualism? No, I do not think so. As we have seen, Ross clearly has in mind dual-nature theories that involve a non-naturalist meta-ethics, the idea being that the ideal dimension of law is a reflection of a mind-independent, non-natural reality. But, as we have also seen, Alexy rejects non-naturalism and appears to espouse instead some sort of constructivism, according to which moral truth or validity, which is what characterizes the ideal dimension of law, is a result of a constructive procedure carried out by moral thinkers. But if constructivists need not be committed to the existence of some sort of non-natural realm of moral norms and values, Alexy need not be - and he does not seem to be - committed to a dual-nature theory that places law partly in some sort of higher realm of norms and values. The natural conclusion, therefore, is that Alexy's dual-nature theory is not a dual-nature theory in the strong sense that Ross was concerned to refute.

Nevertheless, Ross's criticism will be worth the attention of anyone who is interested in Alexy's dual-nature theory. For one thing, one might wish to reject Alexy's constructivism, conceived as a meta-ethical theory, and insist that any defensible meta-ethics has to be non-naturalist. Certainly, Ross and the other Scandinavian realists assumed that the main contenders in the field of meta-ethics were non-cognitivism and non-naturalism (intuitionism).

\section{ROSS' CRITIQUE-AN ASSESSMENT}

We have seen that Ross objects to dual-nature theories, that they give rise to troublesome antinomies, while pointing out that one could avoid the dualism and therefore the antinomies not by eliminating the concept of validity, but by espousing a non-cognitivist instead of a non-naturalist account of claims of legal validity. I have not, however, discussed critically Ross's claims (i) that there is in the concept of law and other fundamental legal concepts a dualism of reality and validity, (ii) that this dualism does give rise to certain antinomies, or (iii) that one could avoid the antinomies by substituting a non-cognitivist account for the non-naturalist account of claims of legal validity. Let us therefore turn to consider these claims now, beginning with (i).

I find Ross's claim that the above-mentioned legal concepts include a dualism of reality and validity rather implausible, yet well worth discussing. The fundamental dualism, as we have seen, is to be found in the concept of law, and the dualism present in the other fundamental legal concepts is the very same dualism. The

89 Ibid., p. 39.

90 Ibíd., p. 173.

91 For criticism, see, e.g., BULYGIN, E (1993). "Alexy und das Richtigkeitsargument [Alexy and the Argument from Correctness]", in: AARNIO, A et al (Eds.)) (1993). Rechtsnorm und Rechtswirklichkeit. Festschrift für Werner Krawietz zum 60. Geburtstag [Legal Norm and Legal Reality. Festschrift for Wernert Krawietz on the Occasion of his 60th Birthday], pp. 19-24. Berlin, Duncker \& Humblot; RAZ, J (2008). "The Argument from Injustice, or How Not to Reply to Legal Positivism", in: PAVLAKOS, G (Ed.,) (2008). Law, Rights and Discourse. The Legal Philosophy of Robert Alexy, pp.17-35. Oxford and Portland, Oregon, Hart Publishing. 
idea, as we have also seen, is that, necessarily, law is at the same time ${ }^{92 .}$ "an observable phenomenon in the world of facts, and ... a binding norm in the world of morals or values", something that is "physical and metaphysical", "real and ideal", "something that exists and something that is valid", "a phenomenon and (... ) a proposition." Thus conceived, Ross says, ${ }^{93}$ law is "an incarnation of the valid, the metaphysical, the ideal in the realm of the actual, the physical, the real."

Ross does not, however, explain in so many words why we should accept his claim that the concept of law includes these two parts. But I believe we can see his claim as the result of a so-called inference to the best explanation ${ }^{94}$. As we have seen, Ross attributes to law two necessary and very different properties, namely, that of being real and that of being valid, and like the other Scandinavian realists he also believes that neither law nor anything else can have these properties at the same time. The reason, according to the Scandinavians, is that these properties belong, and must belong, in some sense in different worlds, and that these worlds just cannot come into contact with each other. As Axel Hägerström, the spiritual father of Scandinavian realism, put it in a critical review of Hans Kelsen's Hauptprobleme der Staatsrechtslehre:

A legal prescript is, in fact, for him [Kelsen] a judgment concerning a supernatural existent, which nevertheless (at least in so far as his view is carried out consistently) must be completely realized in the world of nature. But this is an absurd idea. The supernatural juridical system cannot be thought of as even existing alongside the natural order. For no knowledge of any reality is possible except through relating its object to a systematically interconnected whole. But the supernatural and the natural systems, as being different in kind, cannot be co-ordinated in a single system. Therefore, so far as I contemplate the one, the other does not exist for $\mathrm{me}^{95}$.

This line of reasoning is difficult to assess, however, because it is difficult to see clearly what is involved in the idea of different kinds of world that cannot be coordinated in a single system. Hence we are left with what I take to be Ross's idea, i.e., that the existence in the concept of law, in the concept of the sources of law, and in the concept of subjective law of the dualism of reality and validity is the best explanation of the existence of the antinomies. We therefore need to consider the purported antinomies carefully to see whether they can be said to exist, and if so, whether they can be said to be a result of the above-mentioned dualism, and whether they can be avoided or in some way neutralized.

As regards point (ii), I find Ross's discussion of the antinomies intriguing and well worth discussing, if not persuasive. But, to begin with, as I see it, Ross has not succeeded in showing that the first antinomy in the concept of law is a result of the dualism of reality and validity, or that the second antinomy in the concept of law arises at all.

The first antinomy, as we have seen, can be described as follows. Whereas the validity of a legal norm, $n$, presupposes that $n$ can be traced back to a source of law, $S L_{1}$, the existence of $S L_{1}$ presupposes the validity of the relevant legal order, $L O$, which in turn depends on the validity of $n$ and other norms - if $S L_{1}$ were not recognized by $L O, S L_{1}$ would not qualify as a source of law, and this means that $S L_{1}$ could not be used to confer legal validity on $n$ and other norms.

92 ROSS, A (1989-1946). Op. cit., p. 11.

93 Ibíd., p. 20. Emphasis omitted.

94 On this topic, see: HARMAN, G (1965)."Inference to the Best Explanation”. The Philosophical Review, 74, pp. 88-95.

95 Hägerström's argument is repeated, in:OLIVECRONA, K (1939). Op. cit., pp. 15-16. See also ROSS, A (1989-1946). Op. cit., pp. $42-44$. The argument is based on a rather difficult analysis of the concept of reality put forward in Hägerström (2013[1939]), which I discuss briefly in: SPAAK, T (2013). "Naturalism and Non-Naturalism in Legal Philosophy: Hägerström on Kelsen", in: ELIAESON, S; MINDUS, P \& TURNER, SP (Eds.,) (2013). Axel Hägerström and Modern Social Theory, pp. 231-255. Oxford, The Bardwell Press. 
The reason why we find ourselves in a predicament is this: Not all systems of norms, or all human behavior, are legal norms, or legally relevant behavior, and this means that we need some way of determining whether a certain system of norms is a legal system or whether certain human behavior is legally relevant behavior. And this, of course, is where the concept of legal validity enters the picture. For only a valid system of norms and only human behavior qualified as legal by a valid system of norms count. Ross does not, however, explain why the distinguishing mark - that which turns $X$ into a legal $X$ - has to be understood in terms of the strong conception of legal validity that he contemplates, or how invoking the strong conception could help us avoid the circle. More specifically, given that the antinomy is that we cannot have law unless we already have sources of law or sources of law unless we already have law, then precisely how could the introduction of the strong conception of legal validity help us? I have no idea. As far as I can see, one could solve this antinomy only by presupposing that one already has law (or sources of law) and go from there. To ask what is logically prior - law or sources of law? seems to be about as fruitful as asking what came first - the chicken or the egg?

As we have seen, the second antinomy in the concept of law can be described as follows. If we conceive of legal rules as imperatives (the thesis), we will be able to predict human behavior if, and only if, we also assume that the citizens will comply with the law, and this will land us in the view that legal rules are hypothetical judgments about human behavior (the antithesis). If, on the other hand, we conceive of legal rules as hypothetical judgments about human behavior (the antithesis), we will be able to explain why people comply with the law if, and only if, we also assume that legal rules are imperatives (the thesis).

I do not, however, find persuasive the claim that dualist theories of law suffer from the second antinomy. Ross appears to believe that an emphasis on the practical nature of legal rules will have to lead to a state of affairs in which law is in some sense cut off from reality, and that the transformation of the thesis into the antithesis is necessary in order to anchor law in reality". . . it will not do to regard the legal validity as perfectly independent and primary in relation to facts. If the law as such does not consist in certain actual functions, it will resolve itself into the merely ideal sphere of morality. There is, therefore, a tendency to make the legal rule a function of the maintenance of the law." (ibid, p. 74)

But if the argument is that one needs to anchor law in reality, in order to maintain some realism in the analysis of legal matters, one could simply follow Kelsen ${ }^{96}$ and insist that the validity of law presupposes, though it is by no means identical to, the social efficacy of law. And if so, one could rest content conceiving of legal rules as imperatives (or norms) and would not have to worry about the transformation of imperatives into hypothetical judgments about human behavior at all. As Kelsen ${ }^{97}$ points out, the question of the relation between the validity and the efficacy of law is one of the most important questions that a legal positivist theory of law faces. There are, he explains ${ }^{98}$, two extreme ways one could go when determining the relation between validity and efficacy. The first alternative is to argue that validity is independent of efficacy, and the second is to argue that validity is identical to efficacy. The first alternative is the one that natural law theorists choose, and the second is the one that certain legal realists opt for, and it is clear that it is these two alternatives that Ross has in mind when he formulates the second antinomy.

Kelsen objects that both alternatives are wrong, however. The trick is to find a middle way, he says, and he points out that he himself defends the view that although validity is something different from efficacy, it nevertheless presupposes efficacy: 
The basis of validity, that is the answer to the question of why the norms of this legal order should be obeyed and applied, is the presupposed basic norm, according to which one should comply with a constitution that is actually enacted and by and large efficacious, and thus with the norms that have been issued in accordance with this constitution and that are by and large efficacious. Through the basic norm, enactment and efficacy have been made the conditions of validity; efficacy in the sense that it must combine with enactment, lest the legal order as a whole, as well as the individual legal norm, lose its validity. A condition cannot be identical to that which is conditioned by it ${ }^{99}$.

I agree with Kelsen. I cannot see that the theorist's wish to anchor law in reality means that the theorist has to conceive of legal norms as hypothetical judgments (that is, predictions) about human behavior. Instead, he can avoid the movement back and forth between reality and validity by insisting that legal norms are precisely norms, not predictions about human behavior, and that they are part of a system of norms that is, on the whole, efficacious. What, exactly, does Ross object to in Kelsen's analysis? I do not know, but he might reason that Kelsen's idea of presupposing efficacy rather than stating it (as he himself does) marks a distinction that is somehow misconceived or of no philosophical significance, ${ }^{100}$ though he does not discuss this distinction in the context of his critique of dual-nature theories either. More specifically, he might reason like those who prefer Bertrand Russell's well-known analysis of the claim "The present king of France is bald", according to which that claim is false, to the alternative analysis (advocated by Peter Strawson and others), according to which the claim is meaningless, not false, on account of the non-existence of the subject of the sentence ${ }^{101}$. The main benefit of Russell's analysis, as I understand it, is that it avoids truth-value gaps, and perhaps Ross could say the same about his (Ross's) analysis compared to Kelsen's. I shall not, however, discuss this question any further.

I conclude that Ross has not given us good reasons to accept the claim that the dualism in the concept of law gives rise to the two antinomies we have considered. While the first antinomy is indeed problematic, it has nothing to do with any dualism of reality and validity. And the second antinomy does not even arise.

Turning to consider Ross's discussion of the antinomies that result from the dualism in the concept of the sources of law, I must begin by saying that I find surprising and unpersuasive Ross's claim that the sources of law must perform simultaneously two different functions, namely, (i) that of endowing norms with legal validity and (ii) that of ensuring that judges and other law-appliers actually apply the law. While I can see that the sources of law must endow norms with legal validity, though not necessarily validity in Ross's strong sense, I do not understand why they would have to ensure that law is socially efficacious, or even how they could do it, even if it were only a matter of judicial application of the law and not social efficacy in general.

99 Translated into English by Robert Carroll. The German original reads as follows: "Grund der Geltung, das ist die Antwort auf die Frage, warum die Normen dieser Rechtsordnung befolgt und angewendet werden sollen, ist die vorausgesetzte Grundnorm, derzufolge man einer tatsächlich gesetzten, im großen und ganzen wirksamen Verfassung und daher den gemäß dieser Verfassung tatsächlich gesetzten, im großen und ganzen wirksamen Normen entsprechen soll. Setzung und Wirksamkeit sind in der Grundnorm zur Bedingung der Geltung gemacht; Wirksamkeit in dem Sinne, daß sie zur Setzung hinzutreten muß, damit die Rechtsordnung als Ganzes ebenso wie eine einzelne Rechtsnorm ihre Geltung nicht verliere. Eine Bedingung kann mit dem von ihr Bedingten nicht identisch sein." KELSEN, H (1960). Op. cit., p. 219.

100 This idea was suggested by Svein Eng in his: "Context or Concept? Kelsen and Ross on Valid Law and Efficacy", in the special working group on Kelsen and the Problem of Normativity at the IVR conference in Belo Horizonte, Brazil, 2013.

101 On the questions see, e.g. GARSON, JW (2006). Modal Logic for Philosophers. Cambridge, Cambridge University Press, pp. 385-394; SAINSBURY, M (2001). Logical Forms. An Introduction to Philosophical Logic. $2^{\text {nd }}$. ed. Oxford, Blackwell, pp. 188-195 
But what about the antinomies? As the reader will remember, the first antinomy in the concept of the sources of law is as follows:

Thesis: "The propositions of the doctrine of the sources of law do not themselves belong to positive law, but are valid independently of a given positive system of law."

Antithesis: "The propositions of the doctrine of the sources of law vary from one legal system to another, and must therefore form part of these."

I agree that this antinomy is problematic. And this is only to be expected, given that it is a version of the first antinomy in the concept of law. I do not, however, find Ross's reasoning persuasive. The problem is that Ross fills the doctrine of the sources of law with too much content when he takes it to cover the interpretation and application of legal rules as well as the process of endowing norms with legal validity. Thus, although Swedish and American (and other) judges do and should invoke preparatory works when interpreting statutes and other enactments, this has nothing to do with the question of legal validity, but simply reflects a commitment in the Swedish and American (and certain other) legal communities to the principles of intentionalist (or historical) and purposive (subjectiveteleological) interpretation. Ross's line of argument here is all the more confusing in light of the fact that, as we have seen (in Section 4), Ross observes that we need to distinguish between the doctrine of the sources of law and the legal (juridical) method, precisely because they concern different phases in legal reasoning (the questions of validity and interpretation, respectively). I conclude that since the doctrine of the sources of law does not, and does not have to, deal with this aspect of legal reasoning, this particular line of argument does not establish the conclusion that the doctrine of the sources of law forms part of the relevant legal order (or concept of law), that is, the antithesis.

Moreover, Ross speaks of the 'concept of law' in an idiosyncratic way. It seems to me that what he really means by the relevant 'concept of law' is the relevant legal order - that is, he means to say that the Swedish, say, doctrine of the sources of law cannot be conceptually independent of Swedish law - and this means that he could, and in my view should, restate his claim in terms of legal orders, as I have done above. I mention this idiosyncratic use of the term 'the concept of law' not because I believe it undermines Ross's argumentation, but because it makes it more difficult to understand what Ross really means. I can only hope that I have understood him rightly here.

But even if one considers Ross's reasoning to be unconvincing, one may well wonder what a doctrine of the sources of law that is conceptually independent of a given legal order might look like. As far as I can see, and as I have indicated above (in Section 4), any given source of law will have to be a source of law of some legal order - if there were no Swedish legal order, there would be no sources of Swedish law. If, however, a source of law has to be the source of law of some legal order, specifically, the legal order in question, then we face a problem of circularity. This is so because (as we have seen) for any source of law, $S L_{1}$, to be a source of law of a given legal order, $L O$, the latter $(L O)$ has to already exist; and the existence of $L O$ in turn presupposes the existence of $S L_{1}$ (or $S L_{2}$ or $S L_{3}$, etc.) - if $S L_{1}$ (or $S L_{2}$ or $S L_{3}$, etc.) did not exist, there would be no $L O$. I can see no way to dissolve this antinomy, except by presupposing that we already have law (or sources of law).

As I said above, this antinomy - that is, the first antinomy in the concept of the sources of law - appears to be more or less identical to the first antinomy in the concept of law. And I adopt the same position in regard to this antinomy that I adopted in regard to the first antinomy in the concept of law, namely, that while it does pose a difficult problem, it has nothing to do with any dualism of reality and validity. 
The second antinomy reads as follows:

Thesis: "The supreme source of law (basis for the knowledge of law) is itself a norm or validity, not a fact."

Antithesis: "The supreme source of law is itself a fact, not a norm (validity)."

I find the second antinomy rather more interesting than the first, but in the end less convincing. To begin with, I cannot see that a tacit presupposition of a fundamental norm that makes the (factual) sources of law legally (or normatively) relevant really must amount to a transformation of the sources of law themselves conceived as facts into sources of law conceived as norms. Consider in this regard the theory of normative legal positivism, according to which we have good normative, even moral, reasons to insist on the social thesis ${ }^{102}$. Clearly, those underlying normative reasons do not transform the social thesis either into a normative thesis about factual sources or into a factual thesis about normative sources. That is to say, the social thesis remains factual even if our reasons for espousing it change from, say, conceptual to normative reasons.

Moreover, the notion that one must move from the idea of sources of law as norms (the antithesis) back to the idea of the sources of law as facts (the thesis) just because one adapts the presupposed constitutional norm in a certain way to the circumstances is also problematic, indeed mistaken. To be sure, Ross is right to point out that Kelsen holds that one should presuppose the basic norm only if it corresponds to an efficacious system of norms ${ }^{103}$. But why would such an adaptation have to mean that the basic norm itself has been transformed from being a (presupposed) norm into being a (presupposed) fact? I cannot see that the fact that the presupposition of the basic norm and, in an indirect and rather weak sense, the content of the basic norm, depend in this way on facts would mean that the basic norm has been (or is being) transformed from a norm into a fact. Nor does Ross explain why this would (have to) be the case. I therefore conclude that the second antinomy in the concept of the sources of law does not arise.

Finally, we have the third antinomy in the concept of the sources of law:

Thesis: "The assumption of a multiplicity of original sources of law is an impossibility."

Antithesis: "The attempt to reduce the multiplicity of sources to a systematic unity is not practicable."

The general idea, as I understand it, is that anyone who starts out by assuming a multiplicity of legal sources will soon see that this is impossible and will therefore attempt to find in these sources a systematic unity, only to find that this is not practicable. That is to say, you are damned if you do (assume a multiplicity of legal sources) and damned if you don't. I am not convinced by Ross's reasoning, however. First, as regards the thesis, Ross does not explain (i) why any attempt to show that that which is derived from one source of law is law in the same sense as that which is derived from a another source of law would have to lack any real foundation, or (ii) why the necessity in some cases of evaluating the situation (on this, see below) would have to undermine the objectivity of law. He might, as regards (i), have in mind John Austin's view that law is the content of a sovereign will, in the sense that it is a set of commands issued by the present sovereign, and that commands issued by previous sovereigns or by subordinate agencies are to be thought of as commands implicitly adopted by the present sovereign on

102 See, e.g., WALDRON, J (2001). "Normative (or Ethical) Positivism", in: COEMAN, J (Ed). (2001). Hart's Postscript, pp. 411-433. Oxford, Oxford University Press.

103 See: KELSEN, H (1960). Op. cit., pp. 215-221. 
the grounds that he (the present sovereign) has not explicitly disavowed them ${ }^{104}$. It is, however, clear that even if Austin did not succeed in his attempt to subordinate some sources of law to his preferred primary source of law, some other writer might well succeed on that count. Munzer ${ }^{105}$, for example, appears to do, or purport to do, precisely what Ross says is not practicable. Ross's brief and curt dismissal of any and all such attempts is simply not persuasive.

As regards (ii), Ross ${ }^{106}$ reasons that if we operate with more than one source of law, we will run the risk of receiving incompatible answers to legal questions from different sources of law, and that if we try to handle this difficulty by ranking the sources of law and saying that a subordinate source of law will be applicable only if one or more higher ranked sources do not contain any applicable norm, we will find that we cannot settle the latter question - whether there is an applicable norm or not except by evaluating the situation. That is to say, we cannot determine in a value-neutral way whether there is a gap in the law because the prior question of whether we can accept the answer given to a legal question when there is no applicable norm presupposes evaluation. For example, can the judge reasonably acquit the accused on the grounds that he assaulted the victim with a hammer while the relevant statutory prohibition speaks only of knives, or should she say instead that the absurdity of an acquittal makes it clear that there is a gap in the law and that he should proceed to consider customary rules? As Ross ${ }^{107}$ puts it, "[t]o the cognitive mind there will never be any 'gap"', and this in turn means that we find ourselves in a situation in which the objectivity, or, as Ross puts it ${ }^{108}$, the possibility of "unconditional knowledge," of law has been compromised. I believe Ross is right in principle about the antithesis, but I also believe that serious problem cases will be rare and that therefore the possibility of objectivity has not been seriously compromised.

I conclude that there is no good reason to accept the thesis, that the assumption of a multiplicity of original sources of law is an impossibility.

The most important objection to Ross's analysis concerns the antithesis, however. For, as far as I can see, Ross does not even try to explain why any attempt to reduce the multiplicity of sources to a systematic unity will not be practicable. Note here that his discussion of the necessity of evaluating the situation and thus undermining the objectivity of law, which could perhaps be understood to concern the idea that reducing a multiplicity of sources to a systematic unity is not practicable, does seem to concern not the antithesis, but the second argument - (ii) - in support of the thesis.

I thus conclude that the alleged third antinomy in the concept of the sources of law does not arise.

Let us, finally, consider the antinomies in the concept of subjective law. The first antinomy, as we remember, has it that the existence of subjective law presupposes the existence of an efficacious legal order (thesis), whereas the existence of an efficacious legal order presupposes the existence of subjective law (antithesis). And it will be remembered that the second antinomy has it that the dutycreating character of the consequences of compulsion presupposes that the consequences are sanctions attaching to compulsion, whereas their character as sanctions attaching to compulsion presupposes that they follow upon the contravention of a duty. That is to say, the consequences of compulsion create a

104 On this see, e.gr., AUSTIN, J (1998-1832). The Province of Jurisprudence Determined and The Uses of the Study of Jurisprudence. With an Introduction by H. L. A. Hart. Indianapolis, Hackett Publishing Company. (The former book was first published 1832 and the latter 1863. The former was published again 1954 by Weidenfield \& Nicholson), p. 32; HART, HLA (1961). The Concept of Law. Oxford, Clarendon Press, pp. 45, 62-64.

105 MUNZER, S (1972). Legal Validity. The Hague, Martinus Nijhoff, pp. 56-69.

106 ROSS, A (1989-1946). Op. cit., p. 137.

107 Ibid., p. 138.

108 Ibídem. 
legal duty if, and only if, they qualify as a sanction, although they qualify as a sanction if, and only if, they follow from a breach of a legal duty.

Ross believes that he can solve the first two antinomies by invoking his solution to the first antinomy in the concept of law ${ }^{109}$, namely, to substitute the idea of legal validity conceived as a behavior attitude for the idea of legal validity conceived as a non-natural property, or, if you will, to substitute a non-cognitivist account of claims of legal validity for a non-naturalist account of such claims. As he puts it, in the case of the first two antinomies:

(...) there is merely a special formulation of the general antinomy between reality and validity in law, which, when the irrational realities are substituted for the rationalized fictions, resolve themselves [that is, the above-mentioned antinomies] in an interaction between actual compulsion and a disinterested behavior attitude (experience of validity) ${ }^{110}$.

But, as I have said, I do not find Ross's attempt to dissolve these antinomies convincing, because I cannot see that the antinomies are in any way a consequence of the alleged dualism of reality and validity. On the contrary, I believe we are stuck with these antinomies whether or not we accept a non-cognitivist account of claims of legal validity. Let me elaborate on this. Like the first antinomy in the concept of the sources of law, the first antinomy in the concept of subjective law is (as Ross notes) a special case of the first antinomy in the concept of law, and this in turn means that it is not a consequence of the dualism of reality and validity. The reason, as we have already seen, is that we could not get rid of the antinomy either by eliminating the concept of legal validity altogether or by reinterpreting claims of legal validity along non-cognitivist lines. For the problem is that we cannot have the one component of the antinomy without already having the other: If there is no subjective law, there will be no efficacious legal order, and if there is no efficacious legal order, there will be no subjective law. And this is indeed a difficult problem, which I do not know how to solve, except by simply presupposing (as we usually and tacitly do) that there already is an efficacious legal order in existence. The antinomy has thus nothing to do with any dualism of reality of validity.

Since the second antinomy in the concept of subjective law is just an alternative formulation of the first antinomy in the same concept, I conclude that although it is very difficult to solve, it has nothing to do with any dualism of reality and validity. The reason, or reasons, are the same as the ones I gave above in my discussion of the first antinomy in the concept of subjective law and (before that) in my discussion of the first antinomy in the concept of law.

The third antinomy in the concept of subjective law, finally, has it that the element of will in the concept of subjective law can neither be retained nor abandoned. More specifically, the problem is that, on the one hand, the concept of will cannot be retained as a constituent part of the concept of subjective law, since we recognize children and mentally handicapped persons as right-holders, although they do not have the requisite will, and, on the other hand, that the concept of will cannot be eliminated as a constituent part of the concept of subjective law, since it is needed in order to distinguish between legal rights and mere reflexes.

As we have seen, Ross ${ }^{111}$ holds that this antinomy depends on the fact that our current understanding of the concept is ambiguous, and he attempts to dissolve (or neutralize) the antinomy by substituting an interpretation of the concept of a legal right, according to which this concept is conceived as a technical concept, for the dominating interpretation, according to which it is the concept of a unified

109 Ibid., p. 202.

110 Ibidem.

111 Ibidem. 
entity that has the non-natural property of validity (or bindingness). He reasons that if we conceive of the concept of a legal right as a technical concept, we will not have to worry about whether it is to be understood in terms of will or in terms of interest, since it will clearly be neither the one nor the other. As should be clear, Ross is here anticipating the analysis put forward in Ross ${ }^{112}$, according to which the term 'legal right' is semantically empty and fulfills a syntactic function only, namely, that of connecting a disjunction of legal conditions with a conjunction of legal consequences.

I believe that Ross is right to point out that neither the will theory nor the interest theory of legal rights is fully satisfactory, though I am less sure that we can avoid the problem identified by Ross by giving up on these theories and accepting instead Ross's connective analysis. True, I have discussed the main difficulties that mar Ross's analysis elsewhere ${ }^{113}$ and have suggested ways to overcome these difficulties. However, it now seems to me that my own attempt to remedy the defects I see in Ross's analysis suffers from a rather serious defect, namely, that it fails to respect the distinction between the semantic and the syntactic dimensions of the analysis. More specifically, in my attempt to remedy the defects in Ross's analysis, I help myself to ideas that clearly belong to the semantic dimension, which Ross was so intent on leaving behind.

As for the third question listed at the beginning of this section, we have seen that Ross thinks he can avoid the dualism of reality and validity by substituting a non-cognitivist account of claims of legal validity for (what he considers to be) the usual non-naturalist account of such claims. He is, however, careful to point out that in doing so, he has not rid himself of the concept of validity, but has reinterpreted this concept in a naturalistically acceptable way ${ }^{114}$. We might say that he has offered a non-cognitivist conception of the concept of validity (on concepts and conceptions, see Dworkin ${ }^{115}$. This point about reinterpretation is very important to Ross, because he believes, as we have seen, that one cannot just discard the concept of validity, if one wants a competent theory of law - if we spirit away the concept of validity, he says ${ }^{116}$, we will be unable to determine what human behavior is legally relevant.

The question, however, is whether Ross has succeeded in avoiding the dualism and the antinomies, or whether he has in reality put forward precisely such a realist, monist theory that he considers to be unable to even find its study object. I am inclined to accept the proposed solution. Kelsen ${ }^{117}$ is not so inclined, however, maintaining as he does that the resulting theory is precisely such a theory that Ross was trying to avoid - that is, a theory that has eliminated the concept of validity and sees law as nothing more than human behavior. Kelsen reasons as follows. He assumes that Ross holds that the very idea of non-natural validity is confused ${ }^{118}$, and that Ross aims to reinterpret claims of validity in such a way that they say that a person who maintains that a legal norm is valid really believes that the body that enacted the norm had legal competence to enact valid legal norms ${ }^{119}$. He then infers ${ }^{120}$ that this means that Ross holds that such a person must believe that the relevant body has a property - legal competence - that does not make any sense, depending as it does on the confused concept of legal

ROSS, A (1957). "Tü-tü”, Harvard Law Review, 70, pp. 812-25. Ross's analysis was originally published in Danish in: Festskrift till Henry Ussing, eds O. A. Borum \& Knud Illum, pp. 468- 484. Copenhagen, Arnold Busck.

113 See: SPAAK, T (2014). "Alf Ross on the Concept of a Legal Right". Ratio Juris, 27, pp. 461-476.

114 ROSS, A (1989-1946). Op. cit., p. 49.

115 DWORKIN, RM (1978). Taking Rights Seriously. $2^{\text {nd }}$. ed. London, Duckworth, pp. 134-136.

116 ROSS, A (1989-1946). Op. cit., p. 49.

117 KELSEN, H (1960). Op. cit., p. 216.

118 See: ROSS, A (1989-1946). Op. cit., p. 77.

119 Ibid., p. 80.

120 KELSEN, H (1960). Op. cit., p. 216. 
validity. And he therefore concludes ${ }^{121}$ that Ross has substituted a belief in a confused property for the confused property itself, that this is not to reinterpret claims of validity but to reject them out of hand, and that Ross is therefore stuck with precisely such a monist, realist theory of law that he (Ross) considers to be seriously inadequate.

Kelsen continues to point out ${ }^{122}$ that if we accept Ross's analysis, we must think of any human behavior as law that has been caused by the mistaken belief that in acting in a certain way one is acting in keeping with an objectively valid normative order. But, he objects, this is a mistake. If one conceives of law as something that is necessarily valid in the psychological sense proposed by Ross, one must also hold - on pain of contradiction - that whenever there is the relevant attitude on the part of the legal subjects, there is law. But, he objects, this is not so ${ }^{123}$. Persons who obey the law can do this for any number of reasons, so there is no guarantee that the reason is a belief in the legal competence of certain organs. As he puts it, "die Frage, ob die rechtsetzende Instanz "kompetent" ist, kommt den sich rechtmäßig verhaltenden Menschen zu allermeist gar nicht ins Bewußtsein."

Kelsen concludes that the relevant concept of legal validity must be 'ought-validity' and that any attempt to spirit away the normative import of the concept of validity will lead to some version of the mistaken predictive theory of legal validity:

As an essential element of the concept of law, 'validity' can be none other than 'ought'validity. Ross rejects the claim of the Pure Theory of Law that the concept of law must embrace the meaning by which the law is directed to the individuals whose behavior it regulates, and that it must therefore be determined as an ought-norm. For - Ross asserts 'ought' has not the true but only a pretended meaning. But he says at the same time "By this, however, I do not mean to say that the legal proposition - as some have believed - can be reinterpreted as a statement in the indicative mood as to what will (probably) happen in the future. This would, in fact, be to overlook the tendency of the legal proposition towards 'what is valid." But if the law is not 'ought,' not norm, but reality, and therefore actual behavior, statements of law, as far as they relate to the behavior determined by the legal norm, can only be statements about a behavior that will likely occur in the future. 'The tendency of the legal proposition' is the meaning of the statement of law. If the meaning of these statements is directed 'towards what is valid,' it cannot be a statement about a fact, for a fact of reality cannot be valid. It can only be a statement of an ought-norm, not a statement that people erroneously believe that they should behave lawfully, but that they should behave lawfully ${ }^{124}$.

I do not, however, believe that Kelsen reads Ross correctly. First, he confuses Ross's noncognitivist account of claims of legal validity with an error-theoretical account of such claims when he

121 Ibíd., pp. 216-217.

122 Ibid., p 217.

123 Ibídem.

124 Translated into English by Robert Carroll. The German original reads as follows: "Als wesentliches Element des Rechtsbegriffs kann 'Geltung' nichts anderes als, Soll'-Geltung sein. Ross lehnt die von der reinen Rechtslehre vertretene Forderung ab, der Rechtsbegriff müsse den Sinn erfassen, mit dem sich das Recht an die Individuen wendet, deren Verhalten es regelt, und müsse daher als Soll-Norm bestimmt werden; denn - so behauptet Ross - 'sollen' sei nicht der wahre, sondern nur ein vorgetäuschter (pretended) Sinn. Aber er sagt zugleich: "By this, however, I do not mean to say that the legal proposition - as some have believed - can be reinterpreted as a statement in the indicative mood as to what will (probably) happen in the future. This would, in fact, be to overlook the tendency of the legal proposition toward 'what is valid."' Aber wenn das Recht nicht Sollen, nicht Norm, sondern Sein (reality) und daher tatsächliches Verhalten ist, können Aussagen über das Recht, sofern sie sich auf das Verhalten beziehen, das in den Rechtsnormen bestimmt ist, nur Aussagen über ein Verhalten sein, das wahrscheinlich in Zukunft stattfinden wird. ,The tendency of the legal proposition', ist der Sinn der Aussage über das Recht. Wenn der Sinn dieser Aussagen gerichtet ist, ,towards what is valid', kann es keine Aussage über eine Tatsache sein, denn eine Seins-Tatsache ist nicht gültig. Es kann nur die Aussage über eine Soll-Norm sein, nicht die Aussage, da $\beta$ die Menschen irriger Weise Glauben, sich rechtmäßig verhalten sollen, sondern daß sie sich rechtmäßig verhalten sollen." Ibíd., pp. 217-218. 
maintains that Ross substitutes a belief in a confused property for the confused property itself (on error theory, see ${ }^{125}$. On a non-cognitivist analysis, there is neither any confused property nor any belief in a confused property. For, on this type of analysis, a claim of legal validity does not express a belief about any property, but an attitude to, or a preference for, the object of evaluation, and this means that the person who makes the claim is not asserting that there is a certain (confused or not confused) natural or non-natural property and that the relevant norm-enacting body has it. Hence Kelsen is mistaken when he attributes to Ross the view that a claim of validity expresses a belief that someone or something has a confused property.

Moreover, if we disregard for a moment the confusion between non-cognitivism and error theory, we see that Kelsen gets things backward when he asserts that if one conceives of law as something that is necessarily valid in the psychological sense, as Ross does, one must also hold that if there is such an attitude on the part of the legal subjects (A), there is law (B). On the contrary, if one conceives of law as something that is necessarily valid in the psychological sense, one must also hold that if there is law $(B)$, then there is the relevant attitude on the part of the legal subjects $(A)$. That is to say, Kelsen confuses the conditional "if $B$ then A" with the conditional "if A then B." Whereas Kelsen objects to the latter ("if $A$ then B"), Ross defends the former ("if B then A").

I conclude that if the relevant legal concepts include a dualism of reality and validity, and if this dualism gives rise to at least some of the antinomies considered above, then Ross's proposed solution is successful. I will have to leave for another day the fundamental meta-ethical question of which meta-ethical theory is the true theory and shall be content to say that non-cognitivism is at least a serious contender in this game. 
AÑO 20, No 71

Octubre - Diciembre

Esta revista fue editada en formato digital y publicada en diciembre de 2015, por el Fondo Editorial Serbiluz, Universidad del Zulia. Maracaibo-Venezuela 